\title{
Chitosan-assisted permeabilization of ATP-biotin for live cell kinase-catalyzed biotinylation
}

\author{
Ahmed E Fouda ${ }^{\ddagger}, 1$, D Maheeka Embogama ${ }^{\ddagger}, 1$, Vindya Ramanayake-Mudiyanselage ${ }^{1}$ \& Mary Kay H \\ Pflum ${ }^{* 1}$ \\ ${ }^{1}$ Department of Chemistry, Wayne State University, 5101 Cass Avenue, Detroit, MI 48202, USA
}

BioTechniques 65: 143-148 (September 2018) 10.2144/btn-2018-0076

Kinases are essential cell signaling enzymes that phosphorylate protein substrates using ATP as the universal cosubstrate. A wide variety of ATP analogs have been used in kinase research, although the studies are limited by the cell impermeability of ATP. Here we describe the use of the cationic polymer deacetylated chitosan to permeabilize ATP analogs for live cell applications, including kinase-catalyzed biotinylation.

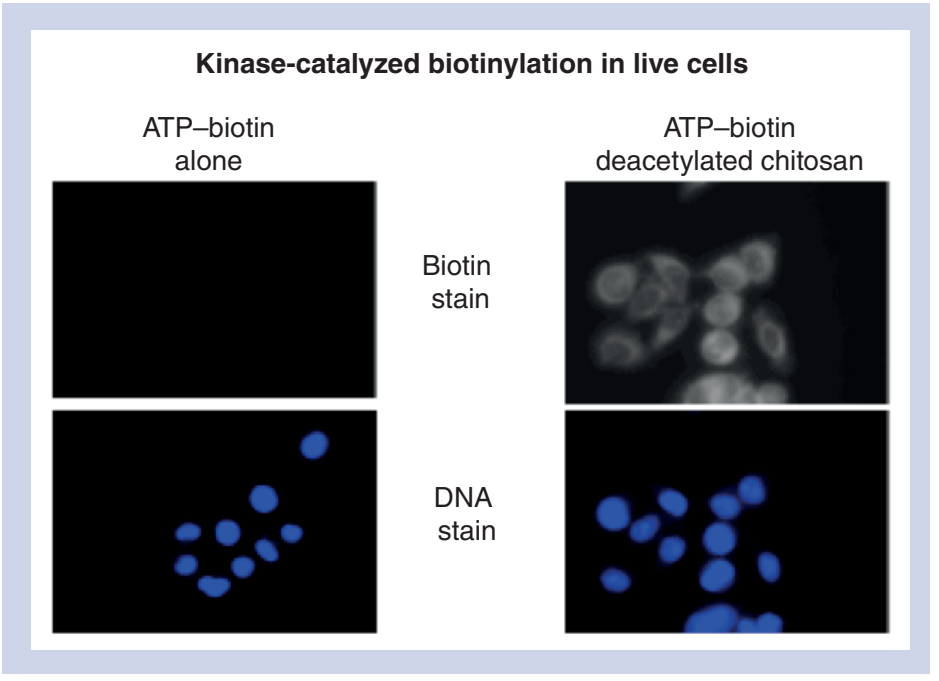

Cell signaling pathways regulate a variety of metabolic processes in living cells. Protein kinases mediate signaling by catalyzing phosphorylation of proteins using ATP as a cosubstrate (Figure 1A) [1]. Alterations in the function of protein kinases can cause cancer [2], Parkinson's [3,4], diabetes mellitus [5] and cardiovascular diseases. With over 500 kinases and thousands of substrates, chemical methods have been essential in the study of kinase-related diseases [6].

One powerful approach to study kinase activity utilizes ATP analogs [7] that contain sugar [8], base [9-11] or triphosphate modifications [12-21]. As one example, our laboratory and others have used $\gamma$-phosphate-modified ATP analogs, including ATP-biotin (Figure 1B), as cosubstrates for kinase-catalyzed labeling reactions [22-27]. ATP-biotin was used to transfer a phosphoramidylbiotin group to proteins through kinase-catalyzed labeling (Figure 1A) [22,28]. The biotin group has the advantage of binding to the streptavidin protein, which allows purification and visualization of biotin-labeled phosphoproteins [29]. Unfortunately, kinase-catalyzed labeling is limited to in vitro lysate-based studies due to the cell impermeability of ATP analogs. The impermeability of ATP analogs has challenged the study of kinase activity and cell signaling in a cellular context. Cellbased experiments would maintain the natural compartmentalization of the cell, which would make kinase studies with ATP analogs more physiologically relevant.

Recently, we reported the first intrinsically cell permeable ATP analog, ATP-polyamine-biotin (APB, Figure 1B), which is compatible with live-cell kinasecatalyzed labeling [27]. The cell permeability of APB is due to the presence of a polyamine linker, which is positively charged under physiological conditions and partially neutralizes the negative charges of the triphosphate. Several additives have also been used to permeabilize ATP and other small molecules. Of these methods, the mild non-ionic detergent digitonin has been used by several research groups to

\section{METHOD SUMMARY}

ATP and its analogs are intrinsically cell impermeable, making cell-based studies with ATP analogs impractical. Here, we document that deacetylated chitosan promoted the delivery of ATP analogs into cells. As an application of the method, cells treated with an ATP-biotin analog/chitosan mixture demonstrated kinase-catalyzed biotinylation of proteins in live cells. 
(A)

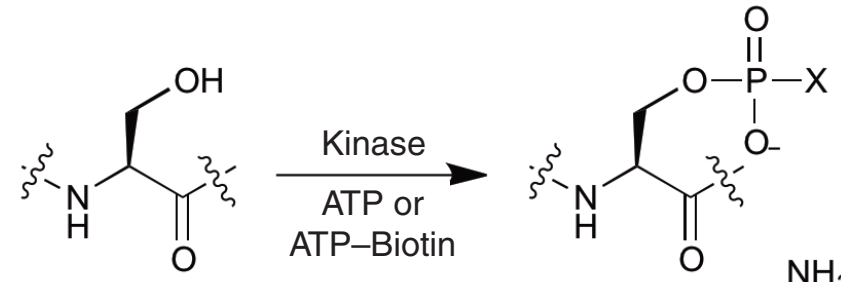

(B)<smiles>[X]P(=O)([O-])OP(=O)([O-])OP(=O)([O-])OC[C@H]1O[C@H](n2cnc3cncnc32)[C@H](O)[C@@H]1O</smiles>
ATP-Biotin, $\mathrm{X}=$<smiles>CCNCCC(C)OCCCNC(=O)C(C)(C)CC1SC[C@H]2NC(=O)N[C@H]12</smiles>

APB, $X=$<smiles>CNCCCCN(C)CCC(C)(C)CNC(=O)C(C)(C)CCC1SC[C@@H]2NC(=O)N[C@H]12</smiles>

(C)

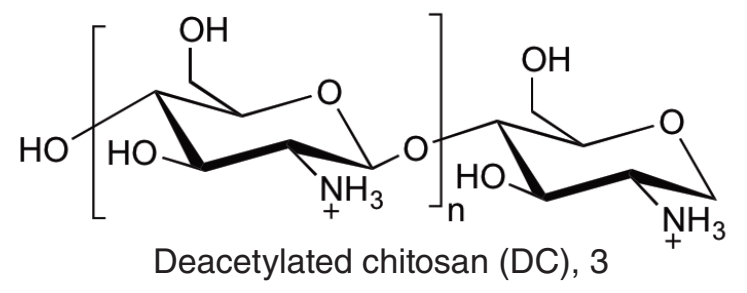

Figure 1. Schemes representing kinase-catalyzed phosphorylation, ATP analogs and deacetylase chitosan. (A) Kinase-catalyzed phosphorylation of proteins using ATP or the ATP analogs, ATP-biotin or APB. (B) The structures of ATP $(X=0)$, ATP-biotin, and APB. (C) The structure of deacetylase chitosan. APB: ATP-polyamine-biotin.

permeabilize ATP analogs [30]. Digitonin interacts with cholesterol and $\beta$-hydroxy glycerol on membranes to facilitate permeabilization [31]. Unfortunately, most digitoninassisted permeabilization studies have been performed with cells in buffer instead of live growth conditions in media $[20,32]$. The physiological relevance of studies using digitonin-permeabilized cells might be compromised due to these 'pseudo in cellulo' conditions. In addition, exogenously added ATP partially reversed permeabilization by digitonin, which might lead to low efficiency [32]. Alternative additives that maintain normal growth conditions and high permeabilization efficiency would have immediate use to analyze kinase-mediated signaling pathways with ATP analogs in live cells.

Deacetylated chitosan (DC, Figure 1C) was reported to chelate ATP and nucleotide-containing drugs to form cell permeable nanoparticles [33]. The cell permeability depended on the ratio of positively charged nitrogens in DC to negatively charged phosphates in ATP (N:P ratio), with the best ratio being 1:1 [33]. In addition, DC was used under normal cell growth conditions in media, allowing experiments to be performed using physiologically relevant conditions. Here, we report the first application of $D C$ as a vehicle to deliver ATP analogs into cells for in cellulo kinasecatalyzed labeling. We also compared the permeabilization and labeling efficiency of DC to digitonin and found higher efficiency with DC. DC permeabilization offers a powerful alternative to use of physiologically compromised digitonin permeabilization or tedious synthesis of intrinsically permeable ATP analogs.

\section{Materials \& methods}

\section{Fluorescence microscopy assay}

HeLa cells $(160,000)$ were grown on a glass cover slip in a 12-well plate overnight in F-12 growth media (500 $\mu$, F-12 media, 10\% FBS, penicillin [9 units], and streptomycin [9 units]) at $37^{\circ} \mathrm{C}$ in a $5 \% \mathrm{CO}_{2}$ environment [34]. Cells were then incubated in serum-free $\mathrm{F} 12$ media for $1 \mathrm{~h}$ at $37^{\circ} \mathrm{C}$ in a $5 \% \mathrm{CO}_{2}$ environment. After the media was removed, cells were incubated for $2 \mathrm{~h}$ at $37^{\circ} \mathrm{C}$ in a $5 \% \mathrm{CO}_{2}$ environment with serum free media (in case of DC) or P buffer (in case of digitonin) $(400 \mu \mathrm{l})$ containing one of the following: ATP (2 mM), ATP-biotin alone $(2 \mathrm{mM}), \mathrm{DC}$ alone $(1.9 \mathrm{mg} / \mathrm{ml})$, digitonin alone (20 $\mu \mathrm{g} / \mathrm{ml})$, ATP-biotin/DC (2 mM/1.9 mg/ $\mathrm{ml})$, or ATP-biotin/digitonin $(2 \mathrm{mM} / 20 \mu \mathrm{g} /$ $\mathrm{ml})$. Cells were washed with DPBS (500 $\mu$, $8 \mathrm{mM} \mathrm{Na}_{2} \mathrm{HPO}_{4}, 1.5 \mathrm{mM} \mathrm{KH}_{2} \mathrm{PO}_{4}, \mathrm{pH} 7.4$, $137.9 \mathrm{mM} \mathrm{NaCl}, 2.6 \mathrm{mM} \mathrm{KCl}$ ) three times, followed by washing with PBS (500 $\mu \mathrm{l}, 2 \mathrm{mM}$ $\mathrm{KH}_{2} \mathrm{PO}_{4}, 10 \mathrm{mM} \mathrm{Na}_{2} \mathrm{HPO}_{4}, \mathrm{pH}$ 7.4, $137 \mathrm{mM}$ $\mathrm{NaCl}, 2.7 \mathrm{mM} \mathrm{KCl}$ ) three times. Paraformaldehyde (4\% in water, $500 \mu$ l) was added and incubated for 20 min at room temperature to fix cells, followed by washing three times with PBS $(500 \mu)$ ). Cells were incubated with Triton X-100 (0.2\% in PBS, $500 \mu$ ) for 5 min at room temperature, followed by washing with PBS $(500 \mu l)$ three times each for 5 min. Cells were incubated with blocking buffer (2\% BSA, 2\% normal goat serum, and 0.2\% gelatin in PBS) for $1 \mathrm{~h}$ at room temperature, followed by incubation of cells with streptavidin-Cy5 $(10 \mu \mathrm{g} / \mathrm{ml})$ in blocking buffer $(50 \mu \mathrm{l})$ for 30 min. Cells were washed with BSA $(0.1 \%$ in PBS, $500 \mu l)$ three times, each for $5 \mathrm{~min}$. DAPI (100 $\mu \mathrm{g} / \mathrm{ml}$ in blocking buffer) was added to cells for $5 \mathrm{~min}$, followed by washing with PBS (500 $\mu$ l) three times each for $5 \mathrm{~min}$. Cover slips were immersed in water then fixed on a glass slide containing a solution of Mowio $^{\circledR} 4-88$ saturated with $\operatorname{DABCO}(6 \mu)$ ), as described by the manufacturer (Sigma-Aldrich, MO, USA). The slide was incubated at $31^{\circ} \mathrm{C}$ for $30 \mathrm{~min}$, then kept at $4^{\circ} \mathrm{C}$ until microscopy. An Olympus microscope (Tokyo, Japan) was used to monitor fluorescence signal using laser wavelengths 


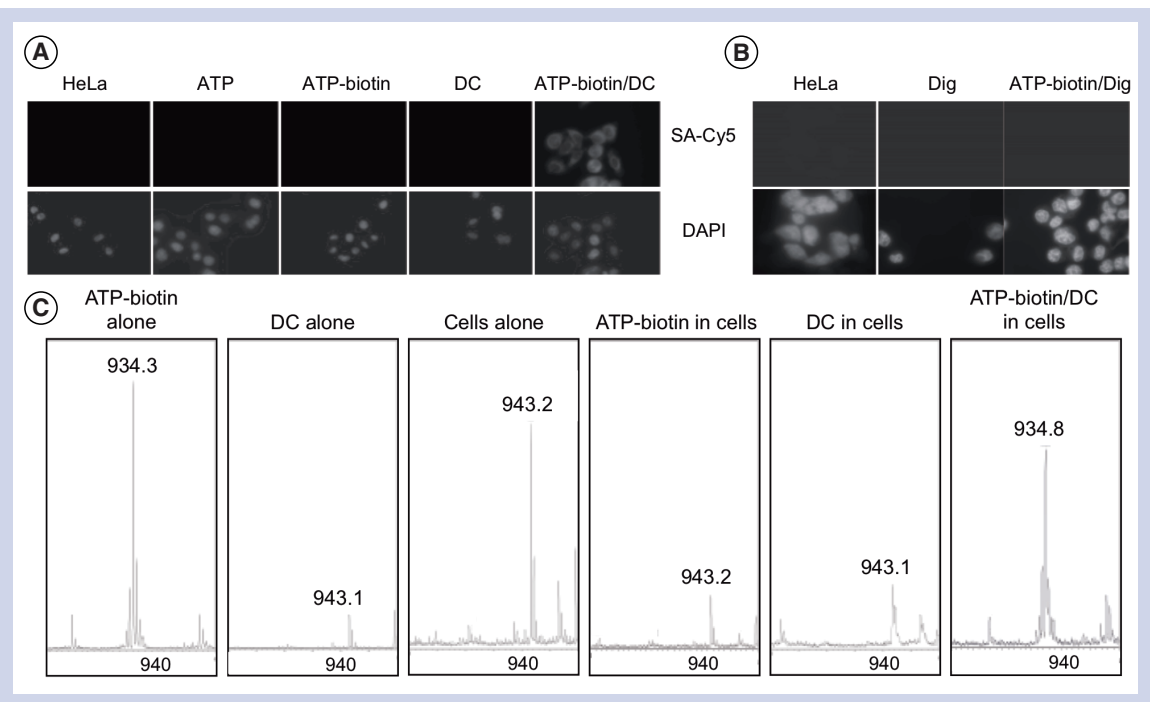

Figure 2. Cell permeabilization of ATP-biotin by deacetylated chitosan. (A) Fluorescence microscopy with DC. HeLa cells were incubated with ATP, ATP-biotin, DC or the ATP-biotin/DC complex, followed by washing, fixing and visualizing with SA-Cy5 to observe biotin (top) or DAPI to stain nuclear DNA (bottom). Repetitive trials are shown in Figure S1. (B) Fluorescence microscopy with Dig. HeLa cells were incubated with digitonin or the ATP-biotin/digitonin complex, followed by washing, fixing and visualizing with SA-Cy5 (top) and DAPI (bottom). Repetitive trials are shown in Figure S2. (C) MALDI monitoring of the ATP-biotin/DC complex. HeLa cells were incubated with ATP-biotin, DC or the ATP-biotin/DC complex, followed by analysis by MALDI-TOF MS. The ATP-biotin peak is at $934 \mathrm{~m} / \mathrm{z}$, whereas the $943 \mathrm{~m} / \mathrm{z}$ peak is a matrix contaminant. Repetitive trials are shown in Figure S3.

DC: Deacetylated chitosan; Dig: Digitonin; SA-Cy5: Streptavidin-Cy5.

corresponding to DAPI (excitation/emission maximum 358/461 nm) and Cy5 (excitation/ emission maximum 678/694 nm). DAPI images were generated at $10 \mathrm{~ms}$, whereas Cy5 images were generated at 500 ms. Three independent trials are shown in Figures 2A, 2B, S1 and S2.

\section{MALDI-TOF in cellulo imaging of ATP-biotin}

HeLa cells $(20,000)$ were suspended in F-12 media containing 11\% FBS, penicillin (9 units) and streptomycin (9 units; $50 \mu \mathrm{l}$ ), and then added to a well of a 96-well plate. An equal volume $(50 \mu \mathrm{l})$ of final concentrations of ATP-biotin (4 mM), DC (3.75 mg/ml), or ATP-biotin/DC complex (4 mM/3.75 mg/ $\mathrm{ml}$ ) was added to separate wells and cells were incubated for $2 \mathrm{~h}$ at $37^{\circ} \mathrm{C}$ in a $5 \% \mathrm{CO}_{2}$ environment. As a control, one well without ATP analog was used as a reference. All reaction volumes were $100 \mu$ l. Cells were collected by centrifugation at 1000 rpm for 5 min at $4^{\circ} \mathrm{C}$, then washed twice with DPBS $(100 \mu l)$. Cell pellets were resuspended in water $(20 \mu \mathrm{l})$. The cell suspension $(1 \mu \mathrm{l})$ was mixed with a saturated solution of $\alpha$-picolinic acid in 50\% acetonitrile $(1 \mu \mathrm{l})$, and then applied to a MALDI plate (Bruker, MA, USA) for MS analysis. The MS spectra were analyzed in negative ion mode for the presence of ATP-biotin at $\mathrm{m} / \mathrm{z}$ 934. Three independent trials are shown in Figures 2C and S3.

\section{Cell-viability assessment of DC}

HeLa cells $(100,000)$ were grown in a 12-well plate for $48 \mathrm{~h}$ in $\mathrm{F}-12$ growth media (F-12 media containing 10\% FBS, penicillin [9 units], and streptomycin [9 units]) at $37^{\circ} \mathrm{C}$ in a $5 \% \mathrm{CO}_{2}$ environment. Various concentrations of the ATP-biotin/DC complex (1 mM/0.9 mg/ml, $2 \mathrm{mM} / 1.88 \mathrm{mg} /$ $\mathrm{ml}, 4 \mathrm{mM} / 3.75 \mathrm{mg} / \mathrm{ml}, 8 \mathrm{mM} / 7.5 \mathrm{mg} / \mathrm{ml}$, or $10 \mathrm{mM} / 9.4 \mathrm{mg} / \mathrm{ml}$ ) were prepared in F-12 growth media as described above. Each ATP-biotin/DC mixture was added separately to cells. Cells were incubated for $2 \mathrm{~h}$ at $37^{\circ} \mathrm{C}$ in a $5 \% \mathrm{CO}_{2}$ environment and then the complex was removed. Cells were washed twice with DPBS $(400 \mu \mathrm{l})$, followed by gentle scraping. Cells were collected by centrifugation at $4^{\circ} \mathrm{C}$ and 1000 rpm for 5 minutes, followed by resuspension in DPBS $(100 \mu \mathrm{l})$. Equal volumes of cell suspension and trypan blue $(0.4 \%$ solution, Invitrogen, CA, USA) were mixed and cells were counted using a hemocytometer. As a control, untreated cells grown in the absence of ATP-biotin/DC were counted, as described. Percentage cell viability was calculated by dividing the number of ATP-biotin/DC-treated live cells by untreated ones, and then multiplying by
100. Kaleidagraph (Synergy Software) was used to calculate the $\mathrm{EC}_{50}$ of ATP-biotin/DC using a sigmoidal binding curve $\mathrm{y}=100 /$ $\left(1+\left(x / E C_{50}\right)^{n}\right.$. The results shown are from three independent trials (Figure S4A \& B).

Cell viability assessment of digitonin Cells were prepared and treated as described for DC treatment, except for the following. Cells were treated with ATP-biotin (4 mM) and digitonin $(20 \mu \mathrm{g} / \mathrm{ml})$ in P buffer (400 $\mu$ l; 25 mM Tris-HCl, pH 7.5, 7.2 mM $\mathrm{Na}_{2} \mathrm{HPO}_{4}, 1.4 \mathrm{mM} \mathrm{KH}_{2} \mathrm{PO}_{4}, \mathrm{pH} 7.4,124 \mathrm{mM}$ $\mathrm{NaCl}, 2.3 \mathrm{mM} \mathrm{KCl}, 2 \mathrm{mM}$ dithiothreitol [DTT], and $10 \mathrm{mM} \mathrm{MgCl}_{2}$ ) containing Xpert protease inhibitor cocktail (1X, GenDEPOT) for $1 \mathrm{~h}$ at $37^{\circ} \mathrm{C}$ in a $5 \% \mathrm{CO}_{2}$ environment. As a control, cells were also treated with ATP-biotin (4 mM) and digitonin $(20 \mu \mathrm{g} / \mathrm{ml})$ in F-12 growth media ( $\mathrm{F}-12$ media, 10\% FBS, penicillin [9 units], and streptomycin [9 units]) for $1 \mathrm{~h}$ at $37^{\circ} \mathrm{C}$ in a $5 \% \mathrm{CO}_{2}$ environment. Digitonin treatment was restricted to $1 \mathrm{~h}$ due to high toxicity at longer times. The results shown are from three independent trials (Figure S4C).

DC-assisted in cellulo kinase-catalyzed biotinylation of HeLa cells HeLa cells $(200,000)$ were prepared and treated in a 12-well plate as described above. The media was removed and then cells were incubated with ATP-biotin alone or the ATP-biotin/DC complex in F-12 growth media under the same cell growth conditions. To optimize the ATPbiotin/DC ratio, cells were incubated with DC alone $(3.75 \mathrm{mg} / \mathrm{ml})$ or different ratios of ATP-biotin/DC complex; 1:1 (4 mM/3.75 mg/ml), 2:1 (4 mM/1.88 mg/ $\mathrm{ml}$ ) and $1.2(4 \mathrm{mM} / 7.50 \mathrm{mg} / \mathrm{ml})$ in F-12 growth media for $2 \mathrm{~h}$ (Figure S6). To optimize the incubation time, the 1:1 ATP_ biotin/DC complex (4 mM/3.75 mg/ml) was incubated for $30 \mathrm{~min}, 1 \mathrm{~h}$ and $2 \mathrm{~h}$ (Figure S7). The optimized conditions for all subsequent studies used ATP-biotin alone (4 $\mathrm{mM}$ ) or the 1:1 ATP-biotin/DC complex (4 mM/3.75 mg/ml) in F-12 growth media with a 2-h incubation period. As a control, cells were preincubated with kinase inhibitor staurosporine $(1 \mu \mathrm{M})$ in F-12 growth media at $37^{\circ} \mathrm{C}$ in a $5 \% \mathrm{CO}_{2}$ environment for 1 $\mathrm{h}$ before incubating with the ATP-biotin/ DC mixture. After the media was removed, cells were washed with DPBS $(400 \mu \mathrm{l})$ two times, harvested by scraping, and collected by centrifugation at $1000 \mathrm{rpm}$ for $5 \mathrm{~min}$ at $0^{\circ} \mathrm{C}$. Cells were lysed by resus- 


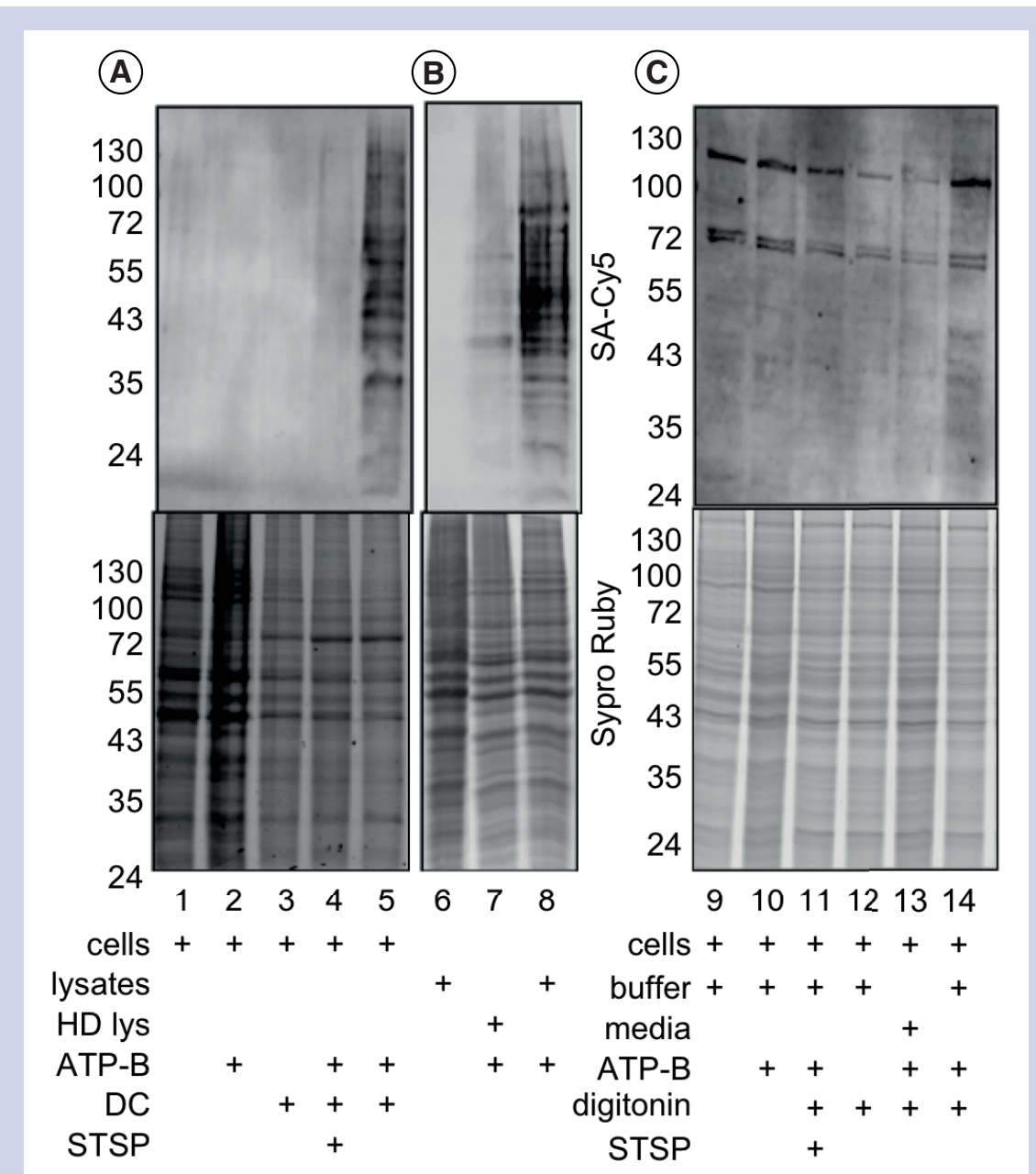

Figure 3. Kinase-catalyzed biotinylation in live cells. (A) DC-assisted in cellulo kinase-catalyzed biotinylation of HeLa cells with ATP-biotin or ATP-biotin/DC complex under normal growth conditions. As a control, HeLa cells were preincubated with kinase inhibitor STSP (lane 4). Repetitive trials are shown in Figure S5A. (B) In vitro kinase-catalyzed biotinylation of HeLa lysates with ATP-biotin. As a negative control, ATP-biotin was incubated with heat-denatured HeLa cell lysates. Repetitive trials are shown in Figure S5B. (C) Digitonin-assisted in cellulo kinase-catalyzed biotinylation of HeLa cells with ATP-biotin under normal growth conditions in either buffer or media. Repetitive trials are shown in Figure S8. For all parts, SDS-PAGE gel analysis was used to separate reaction mixtures and gels were visualized with SA-Cy5 (top) or SYPRO ${ }^{\circledR}$ Ruby total protein stain (bottom).

SA-Cy5: Streptavidin-Cy5; STSP: Staurosporine.

pending in lysis buffer $(21 \mu \mathrm{l}, 50 \mathrm{mM}$ Tris, pH 8.0, $150 \mathrm{mM} \mathrm{NaCl}, 0.5 \%$ Triton X-100, $10 \%$ glycerol, and $1 \mathrm{X}$ protease inhibitor cocktail [GenDepot]) and incubating on ice for 30 min with rocking. Lysates were collected by removing cell debris through centrifugation at 13,200 rpm for $10 \mathrm{~min}$ at $4^{\circ} \mathrm{C}$. SDS-PAGE gel analysis (10\%) was used to separate the proteins in the cell lysates and proteins were visualized by SYPRO ${ }^{\circledR}$ Ruby stain (ThermoFisher, MA, USA). Biotinylation was detected with a streptavidin-Cy5 conjugate (Life Technologies, CA, USA) after transferring onto a polyvinylidene difluoride membrane (Immobilon-P, Milipore, MA, USA). The gels were imaged using a Typhoon imager (GE
Healthcare Life Sciences, IL, USA) using excitation and emission wavelengths of $650 \mathrm{~nm}$ and $670 \mathrm{~nm}$. Three independent trials are shown in Figure $3 \mathrm{~A}$ and S5A.

\section{Digitonin-assisted in cellulo biotinylation in buffer \& media}

HeLa cells $(200,000)$ were prepared and treated in a 12-well plate as described above. Cells were then treated with ATPbiotin ( $4 \mathrm{mM}$ ) in the absence or presence of digitonin $(20 \mu \mathrm{g} / \mathrm{ml})$ in P buffer $(400 \mu \mathrm{l})$ for $1 \mathrm{~h}$ at $37^{\circ} \mathrm{C}$ in a $5 \% \mathrm{CO}_{2}$ environment. To confirm labeling was kinase dependent, cells were preincubated with staurosporine $(1 \mu \mathrm{M})$ in $\mathrm{P}$ buffer $(400 \mu \mathrm{l})$ for $30 \mathrm{~min}$ at $37^{\circ} \mathrm{C}$ in a $5 \% \mathrm{CO}_{2}$ environment before removal and subsequent addition of ATP-Biotin (4 mM) and digitonin $(20 \mu \mathrm{g} / \mathrm{ml})$ with staurosporine $(1 \mu \mathrm{M})$ in $\mathrm{P}$ buffer $(400 \mu \mathrm{l})$. As a comparative control, cells were treated with ATPbiotin $(4 \mathrm{mM})$ and digitonin $(20 \mu \mathrm{g} / \mathrm{ml})$ in F-12 growth media $(400 \mu l)$ for $2 \mathrm{~h}$ at $37^{\circ} \mathrm{C}$. After incubation, the buffer or media was removed, cells were washed with DPBS $(400 \mu l)$ three times, harvested by scraping, and collected by centrifugation at $1000 \mathrm{rpm}$ for 5 min at $0^{\circ} \mathrm{C}$. Cell lysates were created and proteins were analyzed by SDS-PAGE as described above. Repetitive trials are shown in Figures $3 \mathrm{C}$ and $\mathrm{S} 8$.

\section{Digitonin-assisted biotinylation of harvested cells in buffer}

HeLa cells $\left(2 \times 10^{6}\right.$ cells) were harvested, washed with DPBS, and permeabilized for 5 min on ice with digitonin $(50 \mu \mathrm{g} / \mathrm{ml})$ in $\mathrm{P}$ buffer $(400 \mu \mathrm{l})$. After permeabilization, the $P$ buffer containing digitonin was removed and cells were washed once with cold DPBS $(400 \mu l)$. Cells were then treated with ATPbiotin (4 mM) in P buffer (400 $\mu$ l) for $2 \mathrm{~h}$ at $31^{\circ} \mathrm{C}$ with mild shaking at $100 \mathrm{rpm}$. As a control, cell pellets were incubated with $\mathrm{P}$ buffer $(400 \mu l)$ in the absence of digitonin before the ATP-biotin was added. After incubation, cells were washed with DPBS $(400 \mu l)$ three times, and cell lysates were created as described above. Proteins were visualized using SDS-PAGE analysis as described above. Repetitive trials are shown in Figure S9.

\section{Kinase-catalyzed}

biotinylation of lysates

HeLa cells $(200,000)$ were prepared and treated in a 12-well plate as described above [34]. Cells were collected and lysates were prepared as described above. Lysates were incubated with ATP-biotin (4 mM) for $2 \mathrm{~h}$ at $37^{\circ} \mathrm{C}$ in a total reaction volume of $20 \mu \mathrm{l}$. As a control, ATP-biotin (4 mM) was incubated with heat denatured cell lysates, which were generated by heating the lysates to $95^{\circ} \mathrm{C}$ for $1 \mathrm{~min}$. Proteins were visualized using SDS-PAGE analysis as described previously. Repetitive trials are shown in Figure 3B and S5B.

\section{Results \& discussion}

To test if DC can promote the cell permeabilization of ATP-biotin, fluorescence microscopy studies were performed. ATP_ biotin and DC were first preincubated to form an ATP-biotin/DC complex. The ATP_ biotin/DC complex was then incubated with 
HeLa cells under normal growth conditions, followed by washing, fixing and staining with SA-Cy5 to detect biotin. As a control, cells were treated with ATP-biotin alone. Using a 1:1 ratio of ATP-biotin:DC and $2 \mathrm{~h}$ incubation, only cells treated with the ATP-biotin/DC complex showed significant fluorescence signal (Figure 2A and S1). ATP-biotin alone in media showed only background fluorescence. As a comparative control, cells were also incubated with an ATP-biotin/digitonin complex. With the same concentration of ATP-biotin (2 mM) used in the DC-assisted permeabilization studies, ATP-biotin/digitonin showed only background fluorescence (Figure 2B and S2). These experiments indicated that DC promotes the cell permeability of ATP-biotin under normal cell growth conditions with high efficiency.

As a secondary method to confirm ATP-biotin cell delivery by DC, mass spectrometry (MS) analysis was used. HeLa cells were incubated with ATP-biotin or the ATP-biotin/DC complex, washed, and analyzed by mass assisted laser desorption ionization-time of flight (MALDI-TOF) MS. Only cells treated with the ATP-biotin/DC complex showed a peak at $934 \mathrm{~m} / \mathrm{z}$ corresponding to ATP-biotin (Figure $2 \mathrm{C}$ and S3). Cells treated with ATP-biotin alone did not show the presence of the $934 \mathrm{~m} / \mathrm{z}$ peak. These results confirm that DC promotes the cell permeability of ATP-biotin.

In preparation for cell labeling, we assessed the dose-dependent cytotoxicity of ATP-biotin/DC in HeLa cells. The ATP-biotin/DC complex showed an $\mathrm{EC}_{50}$ of $8.0 \pm 0.6 \mathrm{mM} / 7.5 \pm 0.6 \mathrm{mg} / \mathrm{ml}$, respectively (Figure S4A). HeLa cells showed viability of $79 \pm 5 \%$ for ATP-biotin/DC concentrations used in later kinase-catalyzed biotinylation reactions (4 mM/3.75 mg/ml, Figure S4B). For comparison, we also tested the cytotoxicity of ATP-biotin/digitonin and observed only $55 \pm 3 \%$ cell viability at the concentrations used in later biotinylation reactions $(4 \mathrm{mM} / 20 \mu \mathrm{g} / \mathrm{ml}$, Figure S4C). Taken together, these studies indicated that DC is less cytotoxic than digitonin at concentrations needed for cell permeabilization.

Having confirmed the cell permeability and low toxicity of DC, kinase-catalyzed biotinylation in live cells was tested. HeLa cells growing in culture were incubated with the ATP-biotin/DC complex, followed by washing, harvesting, lysis and separation of proteins by SDS-PAGE. Biotinylation was observed in cells treated with the ATPbiotin/DC complex (Figure 3A and S5A, lane 5), which is consistent with cell permeability. As a control, HeLa cells pretreated with the kinase inhibitor, staurosporine, showed reduced biotinylation (Figure $3 \mathrm{~A}$ and S5A, lane 4), which confirmed that biotinylation is kinase dependent. ATP-biotin alone did not show labeling (Figure 3A and S5A, lane $2)$, which indicated that $D C$ is required for cell permeability. Although several ATP_ biotin:DC ratios were tested (Figure S6), maximal labeling and minimal precipitation were obtained with a 1:1 ratio of ATP_ biotin:DC, which is consistent with prior reports studying DC-assisted cell permeability [33]. Biotinylation was observed after $30 \mathrm{~min}, 1 \mathrm{~h}$ and $2 \mathrm{~h}$ incubation periods (Figure S7), although a $2 \mathrm{~h}$ incubation time was selected to be consistent with earlier work in lysates. These experiments establish that DC-permeabilization is compatible with live-cell labeling.

As a comparative control, we tested the ability of digitonin to promote live-cell kinasecatalyzed labeling. Using similar conditions to the DC permeabilization studies, cells were incubated with an ATP-biotin/digitonin mixture under normal growth conditions and then analyzed by gel methods. No biotinylation was observed (Figure 3C, lane 13 and Figure S8, lane 5), indicating low efficiency of permeabilization. Similar results were also observed when cells were incubated with an ATP-biotin/digitonin mixture in buffer (Figure 3C, lane 14 and Figure S8, lane 6) [35]. As a further comparison, harvested cells were digitonin-permeabilized in buffer using published conditions [20]. In this case, cells were harvested, washed permeabilized with digitonin in buffer, and then incubated with ATP-biotin in buffer. With harvested cells, biotinylation of cellular proteins was observed (Figure S9, lanes 4 and 8), although at lower levels compared with DC-assisted biotinylation (Figure 3A and S5A, lane 5). These results document that DC permeabilization offered greater labeling efficiency under normal cell growth conditions compared with digitonin permeabilization.

Most experiments with ATP analogs have been performed in lysates, not live cells, due to the lack of permeability. With a method for ATP permeabilization, we wondered if studies with ATP analogs in live cells would show significant differences compared with lysate-based experiments. To compare in cell with in vitro kinase-catalyzed biotinylation, ATP-biotin was incubated with HeLa cell lysates and biotinylated proteins were analyzed by gel methods (Figure 3B and S5B). The extent of in-cell DC-assisted biotinylation (Figure 3A and S5A, lane 5) compared with in vitro labeling (Figure 3B and S5B, lane 8) was different. In particular, lysate biotinylation produced different labeled bands compared with in cellulo labeling. The differences observed with DC-assisted in-cell biotinylation compared with lysate labeling are consistent with earlier studies using an intrinsically cell-permeable ATP-biotin analog [27]. The difference in biotinylation in live cells versus lysates might be due to cellular compartmentalization, which suggests that ATP-biotin labeling in live cells will better reflect the cellular phosphoproteome than lysate-based labeling.

In conclusion, this study documents use of DC to permeabilize ATP analogs for cell-based studies. Compared with other methods, DC-assisted permeabilization offers several advantages. DC can be generally applied to permeabilize any ATP analog, which avoids synthesis of intrinsically cell-permeable ATP derivatives. Importantly, DC permeabilization is compatible with normal cell growth conditions for studies in a physiologically relevant environment. In fact, a comparison of live-cell versus lysate labeling documented differences in the quality of biotinylation, suggesting that in-cell studies will be valuable. DC permeabilization represents an exciting and enabling advance to study cell signaling using ATP analogs under physiologically relevant conditions.

\section{Author contributions}

AEF performed all experiments with DC, except Figures S6 and S7, which were performed by VR. DME performed all experiments with digitonin. MKHP conceived the project and assisted in the experimental design and interpretation. All authors contributed to writing the manuscript.

\section{Acknowledgments}

We thank Xiang-Dong Zhang for technical support and usage of the fluorescence microscope, Lumigen Instrumentation Center for the use of the MALDI-TOF instrument, and P Dedigama, A Gamage, and $\mathrm{N}$ Acharige for comments on the manuscript. 


\section{Financial \& competing interests disclosure}

This work was supported by the National Institutes of Health (GM079529) and Wayne State University. The content is solely the responsibility of the authors and does not necessarily represent the official views of the National Institutes of Health. This paper is subject to the NIH Public Access Policy. The authors have no other relevant affiliations or financial involvement with any organization or entity with a financial interest in or financial conflict with the subject matter or materials discussed in the manuscript apart from those disclosed.

No writing assistance was utilized in the production of this manuscript.

\section{Open access}

This work is licensed under the Creative Commons Attribution 4.0 License. To view a copy of this license, visit http://creativecommons.org/licenses/by/4.0/

\section{Supplementary data}

To view the supplementary data that accompany this paper please visit the journal website at: www.future-science. com/doi/suppl/10.2144/btn-2018-0076

\section{References}

Papers of special note have been highlighted as:

- of interest; $\bullet$ of considerable interest

1. Johnson SA, Hunter T. Methods for deciphering the kinome. Nat. Methods 2, 17-25 (2005).

2. Cohen P. Protein kinases - the major drug targets of the twenty-first century. Nat. Rev. Drug Discov. 1, 309-315 (2002).

3. Satake W, Nakabayashi Y, Mizuta I et al. Genome-wide association study identifies common variants at four loci as genetic risk factors for Parkinson's disease. Nat. Genet. 41, 1303-1307 (2009).

4. Dachsel JC, Farrerl MJ. LRRK2 and Parkinson disease. Arch. Neurol. 67, 542-547 (2010).

5. Koya D, King GL. Protein kinase $C$ activation and the development of diabetic complications. Diabetes 47, 859-866 (1998).

6. Manning G, Whyte DB, Martinez R, Hunter T, Sudarsanam S. The protein kinase complement of the human genome. Science 298(5600), 19121934 (2002).

7. Anthony TM, Dedigama-Arachchige PM, Embogama DM, Faner TR, Fouda AE, Pflum $\mathrm{MKH}$. ATP analogs in protein kinase research. In: Kinomics: Approaches and Applications. Martic S, Kraatz HB (Eds). VCH-Wiley (2014).
8. Ni Q, Shaffer J, Adams JA. Insights into nucleotide binding in protein kinase A using fluorescent adenosine derivatives. Protein Sci. 9(9), 1818-1827 (2000).

9. Shah K, Liu Y, Deirmengian C, Shokat KM. Engineering unnatural nucleotide specificity for Rous sarcoma virus tyrosine kinase to uniquely label its direct substrates. Proc. Natl Acad. Sci. USA 94, 3565-3570 (1997).

10. Liu Y, Shah K, Yang F, Witucki L, Shokat KM. A molecular gate which controls unnatural atp analogue recognition by the tyrosine kinase V-Src. Bioorg. Med. Chem. 6, 1219-1226 (1998).

11. Couzens AL, Gill RM, Scheid MP. Characterization of a modified ROCK2 protein that allows use of N6-ATP analogs for the identification of novel substrates. BMC Biotechnol. 14, 2 (2014).

12. Hastie CJ, McLauchlan HJ, Cohen P. Assay of protein kinases using radiolabeled ATP: a protocol. Nat. Protocols 1(2), 968-971 (2006).

13. Eckstein F. Nucleoside phosphorothioates. Annu. Rev. Biochem. 54, 367-402 (1985).

14. Wang Z, Lee J, Cossins AR, Brust M. Microarraybased detection of protein binding and functionality by gold nanoparticle probes. Anal. Chem. 77(17), 5770-5774 (2005)

15. Wang Z, Lévy R, Fernig DG, Brust M. Kinasecatalyzed modification of gold nanoparticles: a new approach to colorimetric kinase activity screening. J. Am. Chem. Soc. 128(7), 22142215 (2006).

16. Song H, Kerman K, Kraatz HB. Electrochemical detection of kinase-catalyzed phosphorylation using ferrocene-conjugated ATP. Chem. Commun. (Camb.) (4), 502-504 (2008).

17. Martic S, Gabriel M, Turowec JP, Litchfield DW, Kraatz HB. Versatile strategy for biochemical, electrochemical and immunoarray detection of protein phosphorylations. J. Am. Chem. Soc. 134(41), 17036-17045 (2012).

18. Wilke KE, Francis S, Carlson EE. Activity-based probe for histidine kinase signaling. J. Am. Chem. Soc. 134(22), 9150-9153 (2012).

19. Lee SE, Elphick LM, Anderson AA et al. Synthesis and reactivity of novel gamma-phosphate modified ATP analogues. Bioorg. Med. Chem. Lett. 19(14), 3804-3807 (2009).

20. Allen JJ, Li M, Brinkworth CS et al. A semisynthetic epitope for kinase substrates. Nat. Methods 4(6), 511-516 (2007).

21. Allen JJ, Lazerwith SE, Shokat KM. Bio-orthogonal affinity purification of direct kinase substrates. J. Am. Chem. Soc. 127(15), 5288-5289 (2005).

22. Green KD, Pflum MH. Kinase-catalyzed biotinylation for phosphoprotein detection. J. Am. Chem. Soc. 129(1), 10-11 (2007). - $\quad$ The first paper describing use of ATPbiotin to label kinase substrates with a biotin tag in cell lysates.

23. Green KD, Pflum MH. Exploring kinase cosubstrate promiscuity: monitoring kinase activity through dansylation. ChemBioChem 10, 234237 (2009).

24. Senevirathne C, Green KD, Pflum MK. Kinasecatalyzed biotinylation. Curr. Protoc. Chem. Biol. 4(1), 83-100 (2012).
25. Suwal S, Senevirathne C, Garre S, Pflum MK Structural analysis of ATP analogues compatible with kinase-catalyzed labeling. Bioconjug. Chem. 23(12), 2386-2391 (2012).

26. Senevirathne C, Pflum MK. Biotinylated phosphoproteins from kinase-catalyzed biotinylation are stable to phosphatases: implications for phosphoproteomics. ChemBioChem 4(3), 381-387 (2013).

27. Fouda AE, Pflum MK. A Cell-permeable ATP analogue for kinase-catalyzed biotinylation. Angew Chem. Int. Ed. Engl. 54(33), 9618-9621 (2015).

28. Senevirathne C, Embogama DM, Anthony TA, Fouda AE, Pflum MK. The generality of kinase-catalyzed biotinylation. Bioorg. Med. Chem. 24(1), 12-19 (2016). - Rigorously characterizes kinasecatalyzed biotinylation with ATP-biotin and 25 kinases representing the kinome family tree.

29. Dunn JD, Reid GE, Bruening ML. Techniques for phosphopeptide enrichment prior to analysis by mass spectrometry. Mass Spectrom. Rev. 29(1), 29-54 (2010).

30. Gonçalves CA, Gottfried C, Dunkley PR. The use of permeabilized cells to assay protein phosphorylation and catecholamine release. Neurochem. Res. 25(6), 885-894 (2000)

31. Holden P, Horton WA. Crude subcellular fractionation of cultured mammalian cell lines. BMC Research Notes 2(2), 243 (2009).

32. Tramontina F, Karl J, Gottfried C et al. Digitoninpermeabilization of astrocytes in culture monitored by trypan blue exclusion and loss of S100B by ELISA. Brain Res. Brain Res. Protoc. 6(1-2), 86-90 (2000)

33. Giacalone G, Bochot Al, Fattal E, Hillaireau H. Drug-Induced nanocarrier assembly as a strategy for the cellular delivery of nucleotides and nucleotide analogues. Biomacromolecules 14, 737-742 (2013). -. Documents the first reported use of chitosan as nanocarriers of nucleotides and nucleotide analogs

34. Fouda AE, Pflum MKH. A cell permeable ATP analogue for kinase catalyzed biotinylation. Angew. Chem. Int. Ed. 54, 9618-9621 (2015). -. Reports the synthesis and characterization of an ATP analog containing a cationic linker to promote cell permeabilization.

35. Banko MR, Allen JJ, Schaffer BE et al. Chemica genetic screen for AMPK $\alpha 2$ substrates uncovers a network of proteins involved in mitosis. Mol. Cell 44(6), 878-892 (2011)

First draft submitted: 18 December 2017; Accepted for publication: 11 July 2018

Address correspondence to: Mary Kay H Pflum, Department of Chemistry, Wayne State University, 5101 Cass Avenue, Detroit, MI 48202, USA; Tel.: +1 313 577 1515; Fax: +1 313577 8822; pflum@wayne.edu $\neq$ Joint first authors

To purchase reprints of this article contact: s.cavana@future-science.com 